\title{
KERENTANAN KEBAKARAN HUTAN BERDASARKAN KARAKTER UMUR TANAMAN JATI
}

\author{
Forest Fire Susceptibility Based on Teak Age Characteristics \\ Fiqri Ardiansyah ${ }^{1}$, Ananto Triyogo ${ }^{1}$ \\ ${ }^{1}$ Jurusan Silvikultur, Fakultas Kehutanan, Universitas Gadjah Mada, Jogjakarta, 55281 \\ E-mail : fiqri.ardiansyah@ugm.ac.id, anantotriyogo@ugm.ac.id
}

Diterima: 22 November 2020, Direvisi: 08 Desember 2020, Disetujui: 29 Januari 2021

DOI: 10.31849 /forestra.v16i1.5530

\begin{abstract}
Forest management in Java dominated with Teak plantation that organize with community. One threats of forest damages is forest fires. Forest fires caused by susceptible fuel, oxygen rate, and fires resource. Teak plantation closed with community activities that using fires within purpose or not. This research aim to identify the effect of plant age towards forest fires susceptibility by combustion rate. This research conducted in Wanagama I EduForest. The effects of plant age towards forest fires susceptibility analysed by bark thickness and water content of bark. Teak bark samples taken on various age of $5^{\text {th }}, 15^{\text {th }}$, and $40^{\text {th }}$. Foresf fires suceptibility observed by combustion test. The effects of teak age towards on bark thickness and water content, combustion rate analysed using anova with $10 \%$ of confident level. The results showed that 1) plant age affecting thickness and water content of teak bark; 2) bark thickness affect fire susceptibility rate of teak on various age, bark thickness has growth along age increase which more tolerant towards of combustion; and 3) Surface forest fires in Wanagama I caused by multiple sources of fire ignition that closed to road accesibility, and the damage mostly occurred until $100 \mathrm{~cm}$ of height from forest ground.
\end{abstract}

Keywords: Teak, Fire, Susceptibility, Age, Wanagama

\section{INTISARI}

Pengelolaan hutan di Jawa didominasi oleh Hutan Tanaman Jati yang dikelola bersama masyarakat. Salah satu ancaman kerusakan dalam pengelolaan hutan jati yaitu kebakaran hutan. Kebakaran hutan terjadi karena bahan bakar yang rentan, oksigen yang melimpah, dan adanya sumber api. Kerentanan kebakaran hutan jati tidak lepas dari aktifitas masyarakat yang bersinggungan dengan api secara sengaja maupun tidak disengaja. Penelitian ini bertujuan untuk mengetahui pengaruh umur tanaman jati terhadap kerentanan kebakaran hutan pada aspek kecepatan terpicu api. Kegiatan ini dilaksanakan di Hutan Pendidikan Wanagama I Gunungkidul. Parameter kerentanan yang diamati adalah ketebalan dan kandungan air kulit batang. Sampel kulit diamati pada tanaman berumur 5, 15, dan 40 tahun. Kerentanan kebakaran yang diuji yaitu kecepatan terpicu api (combustion test). Pengaruh umur terhadap tebal kulit dan kadar air, serta kecepatan terpicunya api dianalisis melalui hasil uji anava $(\alpha=10 \%)$. Hasil penelitian menunjukkan bahwa 1) Umur tanaman mempengaruhi ketebalan dan kandungan air kulit batang jati; 2) Tebal kulit batang jati berpengaruh pada ketahanan 
terhadap api, ketebalan kulit batang yang bertambah seiring pertambahan umur semakin toleran terhadap api; dan 3) Kebakaran permukaan hutan jati disebabkan oleh lebih dari 1 sumber api yang dekat dengan jalur aksesibilitas, dengan distribusi keruskaan pada ketinggian hingga $100 \mathrm{~cm}$ dari permukaan tanah.

Kata kunci: Jati, Kebakaran, Kerentanan, Umur, Wanagama

\section{PENDAHULUAN}

Laju deforestasi di Indonesia semakin meningkat dari tahun ke tahun. Pada periode 2009-2016, terjadi peningkatan laju deforestasi hingga 94 ribu hektare/tahun (FWI., 2018). Laju hilangnya hutan tersebut disebabkan oleh aktivitas perkebunan, kebakaran hutan, investor, dan petani pelopor. Kebakaran pada tahun 2015 mencapai 261.060,44 Ha (Sipongi., 2018). Kejadian kebakaran hutan terus meningkat dari tahun 2013 hingga 2015. Berbagai upaya telah dilakukan untuk mengurangi luasan hutan yang terbakar dari tahun ke tahun. Upaya tersebut dilakukan melalui pencegahan kebakaran hutan, dan penegakan hukum guna menanggulangi potensi kebakaran hutan. Kebakaran hutan di Indonesia sering terjadi di lahan gambut (Luar Pulau Jawa), dan lahan tanah mineral (Pulau Jawa). Kebakaran hutan menimbulkan dampak berupa kerusakan kayu, kematian pohon, kerusakan HTI, gangguan kesehatan dan transportasi
(Rasyid., 2014). Dampak negatif kebakaran pada keanekaragaman hayati yaitu hutan yang terbakar berat akan sulit dipulihkan, karena struktur tanahnya rusak. Selain itu, lahan bekas terbakar akan mengalami penurunan kualitas lahan seperti erosi yang tinggi.

Berdasarkan UU RI no. 41/1999 tentang Kehutanan, Hutan merupakan suatu kesatuan ekosistem berupa hamparan lahan berisi sumber daya alam hayati yang didominasi pepohonan dalam persekutuan alam lingkungannya, yang satu dengan lainnya tidak dapat dipisahkan. Kebakaran hutan berdasarkan SK. Menhut No. 195/Kpts-II/1996 adalah suatu keadaan dimana hutan dilanda api sehingga mengakibatkan kerusakan hutan dan hasil hutan yang menimbulkan kerugian ekonomi dan lingkungannya. Kebakaran hutan merupakan reaksi kimia yang terjadi karena terpenuhinya komponen konsep segitiga api yang optimum. Kebakaran lahan dan hutan dapat terjadi apabila terpenuhi syarat 
segitiga kebakaran yang terdiri dari sumber api, bahan bakar, dan iklim pada kondisi optimum (Sumardi dan Widyastuti., 2007; Akbar., 2016). Bahan bakar adalah semua vegetasi penyusun hutan yang hidup maupun yang mati, dan lapisan bahan organik tanah hutan. Tingkat kerentanan setiap jenis bahan bakar terhadap terpicunya api memiliki karakter yang berbeda-beda. Faktor-faktor yang dapat mempengaruhi kecepatan objek terpicu api (combustion) adalah kandungan air, kandungan senyawa flamable tanaman baik pada batang maupun daun, dan karakter morfologi tanaman. Api akan terpicu dengan mudah dan menyebar secara masif pada bahan bakar kering dengan kelembaban yang rendah (NWCG., 2005). Pada pohon, kebakaran permukaan mampu mematikan bagian kulit kayu tetapi bagian kayu masih dapat tetap hidup (Akbar., 2016).

Kebakaran hutan di Pulau Jawa umumnya terjadi pada hutan tanaman jati. Jati adalah salah satu spesies slow growing yang banyak dikembangkan masyarakat di Pulau Jawa. Jenis tanaman ini merupakan salah satu jenis kayu yang bahyak diminati karena corak yang unik dan elegan, kuat, awet, dan stabil (Wahyudi et al., 2014). Jenis tanaman ini termasuk dalam famili Lamiaceae. Daerah yang menjadi tempat pertumbuhan jati adalah daerah dengan musim kering yang nyata, dengan intensitas curah hujan antara 1200-3000 mm/tahun, intensitas cahaya $75-100 \%$ dan suhu berkisar $22^{\circ} \mathrm{C}-31^{\circ} \mathrm{C}$. Jati akan tumbuh dengan optimal pada ketinggian 0-700 m diatas permukaan laut (Pudjiono., 2014). Tanaman jati memiliki kulit yang relatif tebal. Kulit batang memilki ketebalan $3 \mathrm{~mm}$ pada tanaman muda, dan dapat mencapai 0,5-0,7 cm pada tanaman tua (Baskorowati dan Fauzi., 2013). Kulit tanaman kayu jati super, umumnya memiliki ketebalan kulit yang lebih tebal dari jati konvensional. Kecenderungan kulitnya menipis dari bagian pangkal ke bagian ujung (Krisdianto dan Sumarni., 2006). Kerapatan dan berat jenis kayu jati dari hutan tanaman cenderung meningkat seiring dengan bertambahnya umur pohon (Wahyudi et al., 2014). Pertumbuhan tanaman jati tersebut dipengaruhi oleh tempat tumbuh dan posisi aksial terhadap pembentukan kulit kayu, dan kayu teras/gubal (Ganis et al., 2010). Pertumbuhan jati juga dipengaruhi oleh 
faktor lingkungan khususnya pada musim kemarau dan penghujan. Semakin besar kelas diameter pohon jati, maka semakin tinggi riap pertumbuhannya (Marsoem., 2013).

Penelitian ini bertujuan untuk mengetahui pengaruh umur tanaman jati terhadap kerentanan kebakaran hutan pada aspek kecepatan terpicu api. Informasi tingkat kerentanan kebakaran berdasarkan umur tanaman jati diharapkan mampu menjadi dasar penentuan prioritas tindakan pencegahan kebakaran hutan. Kerentanan adalah kondisi yang ditentukan oleh faktor atau proses fisik sosial ekonomi dan juga lingkungan, yang meningkatkan kerapuhan masyarakat/komunitas karena dampak kerawanan (JICA., 2009). Kajian analisis kerentanan merupakan upaya yang dapat dimanfaatkan menjadi informasi risiko (Hizbaron et al., 2010). Kerentanan fisik merupakan kondisi fisik yang bisa meningkatkan rawannya sebuah komnitas terhadap dampak bahaya, misalnya umur tanaman dan materi penyusun hutan. (ADPC., 2006). Dalam memahami kajian kebakaran hutan diperlukan identifikasi faktor yang saling berkaitan yaitu kerentanan, kerawanan, dan kemampuan (Jaswadi et al., 2012).

Penelitian ini penting untuk dilakukan karena hutan jati di jawa sangat erat hubungannya dengan masyarakat sekitar hutan. Seringkali kejadian kebakaran hutan jati disebabkan oleh aktifitas masyarakat sekitar yang melakukan pembersihan lahan, maupun ketidaksengajaan dalam menggunakan sumber api. Hasil penelitian ini berupa tingkat kerentanan jati pada berbagai umur diharapkan mampu menjadi pertimbangan dalam pengembangan sistem kelola perhutanan jati bersama masyarakat yang lebih baik. Identifikasi kerentanan jenis jati terhadap kebakaran hutan pada berbagai umur dapat digunakan sebagai rujukan pengakjian kerawanan kebakaran hutan menggunakan sistem penginderaan jauh serta penentuan kebijakan pengelolaan pertanaman jati di lapangan. terhadap Penelitian ini memiliki tujuan umum untuk mengetahui pengaruh umur tanaman jati terhadap kerentanan kebakaran hutan, dengan tujuan khusus yaitu 1) Mengetahui pengaruh umur terhadap tebal kulit jati dan kandungan air kulit jati, 2) Mengetahui pengaruh tebal dan kandungan air kulit jati 
kerentanan kebakaran pada berbagai umur, dan 3) Mengetahui pola perilaku api pada tegakan jati umur sedang.

\section{METODE PENELITIAN}

Penelitian ini dilakukan di Hutan Pendidikan Wanagama I, Gunungkidul (Petak 17 dan Petak 5) dan Laboratorium Perlindungan dan Kesehatan Hutan, Fakultas Kehutanan, Universitas Gadjah Mada pada bulan April - November 2019.

Peralatan yang digunakan dalam penelitian ini diantaranya adalah tallysheet, GPS, rollmeter, diameter tape, tatah, timbangan digital, oven laboratorium, stopwatch, lampu bunsen, korek api, dan pinset. Bahan penelitian yang digunakan adalah sampel kulit tanaman jati pada 3 variasi umur tegakan. Kerentanan jati terhadap kebakaran diidentifikasi pada karakteristik kulit batang. Sampel kulit batang berdiri diambil pada tegakan jati berumur 5, 15, dan 40 tahun. Sampel tersebut tersebar di petak 17 (tahun tanaman 2014 dan 2004), dan petak 5 (tahun tanam 1979).

Penelitian ini dimulai dengan survei pendahuluan, pengambilan data lapangan, pengamatan data laboratorium, analisa data, dan formulasi kesimpulan. Pengambulan data lapangan dilakukan dengan prosedur berikut :

a. Petak ukur berukuran $20 \times 20$ meter sebanyak 10 buah diletakkan secara random di tegakan jati bekas kebakaran hutan.

b. Pengukuran kerusakan meliputi tinggi kerusakan (bekas luka terbakar) pada bagian batang tanaman jati, luas kerusakan, dan keliling pohon jati.

c. Tinggi titik pengambilan sampel kulit kayu jati pada 3 titik, dilakukan berdasarkan hasil rerata tinggi bekas kebakaran pada batang.

d. Sampel kulit jati diambil pada berbagai umur tanaman jati (5 tahun, 15 tahun, dan 40 tahun). Jumlah pohon sampel yang diambil sebanyak 30 pohon jati atau 10 individu per umur tegakan. Pengambilan sampel dilakukan dengan mengkoyak kulit batang pohon jati hingga bagian kambium. Ukuran sampel yang digunakan yaitu $4 \mathrm{~cm} \mathrm{x} 4$ cm. Sampel diambil pada 4 sisi arah mata angin (utara-selatan, dan barattimur).

Mekanisme pengamatan untuk mengetahui pengaruh umur terhadap tebal 
dan kandungan air kulit batang jati dilakukan dengan menimbang berat dan tebal kulit batang setiap sampel dalam kondisi basah dan kering tanur. Sampel kulit yang telah ditimbang berat dan dimensi ketebalan kulitnya dalam keadaan basah, kemudian dikeringkan hingga mencapai kondisi kering tanur (pengeringan pada suhu $105^{\circ} \mathrm{C}$ selama 36 jam). Kadar air sampel kulit kayu dihitung menggunakan rumus Haygreen dan Bowyer (1953) :

$$
\text { Kadar air }(\%)=\frac{(\text { berat basah }- \text { berat kering })}{\text { berat kering }} \times 100 \%
$$

Kadar air segar merupakan ukuran banyaknya air saat pohon masih berdiri (Marsoem et al., 2014).

Pengaruh tebal dan kandungan air kulit kayu jati pada berbagai umur terhadap kecepatan terpicunya api dalam penelitian ini diamati melalui uji combustion. Respon kecepatan nyala api terhadap sampel kulit tanaman jati dilakukan pada sampel segar dan sampel kering tanur. Pengamatan respon kecepatan nyala api dilakukan secara kuantitatif melalui lama nyala api yang mulai membakar sampel, dan secara kualitatif melalui deskripsi kerusakan pada sampel (Rianawati., 2007). Durasi nyala api diamati dengan menggunakan stopwatch yang mengindikasikan respon kecepatan terpicunya sampel terhadap api, yang dinyatakan dalam menit/detik. Sampel yang dibakar merupakan sampel yang telah diukur berat kulit, tebal kulit, dan kandungan air kulit. Indikator yang menentukan kerentanan terhadap kebakaran yang diamati adalah tebal kulit, dan kandungan air kulit. Pembakaran dilakukan secara seragam pada kondisi ruang dan sumber api yang sama. Sumber api yang digunakan dalam pengujian adalah lampu bunsen yang telah diatur ketinggian sumbunya, sehingga menciptakan nyala api yang stabil. Kelimpahan oksigen di udara diseragamkan dengan melakukan pembakaran di dalam ruangan pada suhu standar ruangan.

Pola perilaku api kebakaran hutan jati umur sedang dipetakan dengan melakukan pencatatan koordinat pohon yang diamati bekas kebakaran pada bagian batang. Pada seluruh objek pengamatan diamati rerata tinggi bekas kebakaran, rerata luas kerusakan pada bagian batang.

Pengaruh umur terhadap pertumbuhan kulit dan kandungan air kulit jati dan (2) pengaruh tebal kulit dan kandungan air 
pada berbagai umur tanaman jati terhadap kerentanan kebakaran dianalisi menggunakan ANAVA (Analisis varian) pada taraf uji $10 \%$, dengan analisis pasca anova LSD dan DMRT (Duncan's Multiple Range Test). Analisis pola perilaku api dilakukan secara deskriptif kuantitatif berdasarkan sebaran tinggi dan luas kerusakan bekas kebakaran.

\section{HASIL DAN PEMBAHASAN}

\section{Pengaruh Umur Terhadap Kandungan}

\section{Air dan Tebal Kulit Batang Jati}

Pertumbuhan tanaman yang berjalan seiring dengan pertambahan umur yaitu pertumbuhan kulit tanaman. Tebal kulit merupakan salah satu indikator pertumbuhan tanaman sebagai hasil dari pertumbuhan sel tanaman melalui proses fisiologis tanaman. Berdasarkan penelitian yang dilakukan oleh Subantoro (2014), kandungan air pada tanaman bervariasi antara $60-90 \%$ tergantung umur, jaringan tanaman, dan lingkungan. Salah satu jaringan yang mampu menampung air dan hasil fotositensis yaitu jaringan epidermis tanaman. Pada tumbuhan, jaringan tanaman berfungsi untuk melindungi organ tumbuhan dari pengaruh lingkungan luar dan menyimpan cadangan air. Kulit batang tanaman dengan karakteristiknya merupakan suatu bentuk pertahanan tanaman terhadap gangguan luarnya, misalnya terhadap api.

\section{a. Kadar Air Kulit Batang Tanaman}

Kadar air kulit batang tanaman merupakan salah satu sifat fisis tanaman yang dipengaruhi oleh umur sebagai salah satu hasil aktifitas fisiologis tanaman. Pertambahan umur tanaman diikuti dengan pertambahan sel muda maupun sel yang sudah mati. Kadar air kulit mengindikasikan kandungan air yang disimpan pada bagian kulit tanaman.

Tabel 1. Hasil Analisis Varians Kadar Air Kulit Batang Tanaman Jati Pada Berbagai Umur Dan Seksi Tanaman

\begin{tabular}{lrrrr}
\hline Sumber variasi & $\begin{array}{r}\text { Deraja } \\
\text { t bebas }\end{array}$ & $\begin{array}{c}\text { Jumlah } \\
\text { kuadrat }\end{array}$ & F hitung & Pr>F \\
\hline Umur & 2 & 25637.42 & 209,86 & $\mathbf{0 , 0 0 0 *}$ \\
Seksi & 2 & 179.51 & 1,469 & 0,236 \\
Umur x Seksi & 4 & 368,62 & 1,51 & 0,207 \\
Error & 81 & 4947,50 & & \\
\hline Total & 89 & 31133,06 & & \\
\hline
\end{tabular}

Hasil analisis varians terhadap kadar air kulit batang tanaman jati (Tabel 1) menunjukkan bahwa umur tanaman memberikan pengaruh yang nyata terhadap kadar air dalam kulit batang tanaman jati di lapangan. Pada berbagai umur, seksi tanaman (atas, tengah, dan bawah) tidak 
memberikan pengaruh yang nyata terhadap kandungan air dalam kulit batang.

Berdasarkan hasil pengujian lanjut pengaruh umur terhadap kandungan air, tanaman jati muda adalah material yang paling berpengaruh terhadap kandungan air dalam kulit batang tanaman (Gambar 2). Hal tersebut terlihat dari perbedaan rerata apabila dibandingkan dengan kelas umur sedang maupun tua melalui uji lanjut DMRT dengan taraf uji 5\%. Kulit tanaman jati memiliki karakteristik yang berbeda pada berbagai umur. Tanaman jati pada umur muda (5 tahun) memiliki morfologi kulit yang kasar dan sedikit beralur. Berbeda dengan kulit batang jati pada umur sedang (15 tahun) dan tua (40 tahun), cenderung memiliki kulit yang lebih tebal namun beralur dalam. Jaringan tanaman pada umur muda yang cenderung meristematis dan tidak beralur memiliki kapasitas menampung kandungan air yang lebih banyak.

Pada Gambar 1, rerata kadar air kulit batang tanaman tertinggi dimiliki oleh tanaman jati pada umur 5 tahun, sedangkan yang terendah pada umur 40 tahun. Kadar air tanaman semakin menurun seiring dengan pertambahan umur tanaman. Hal tersebut didukung oleh perkembangan morfologi kulit tanaman jati yang semakin menunjukkan alur-alur dalam pada permukaan kulitnya dan membentuk sel-sel mati dengan kemampuan menampung cadangan air yang minimum.

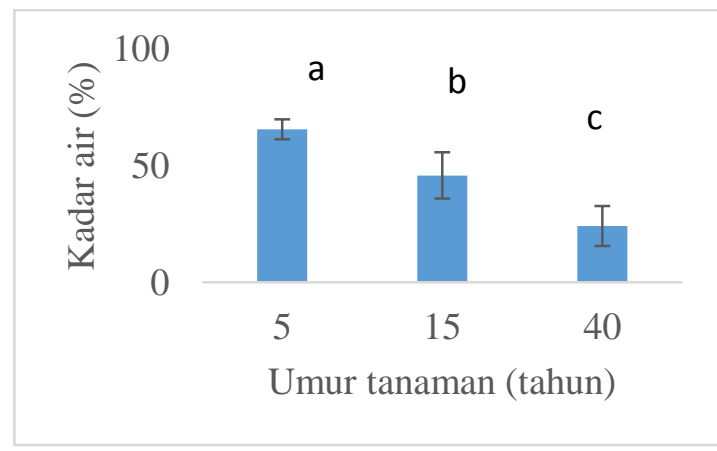

Gambar 1. Rerata Kadar Air Kulit Batang Tanaman Berdasarkan Umur Tanaman Jati

Hasil analisis varians kadar air pada berbagai seksi tanaman tidak memberikan pengaruh yang signifikan, hal tersebut memiliki arti bahwa kadar air pada setiap seksi tanaman tidak memiliki perbedaan yang signifikan pada kandungan air dalam kulit batang tanaman jati. Kulit batang tanaman pada berbagai ketinggian dari permukaan tanah memiliki kandungan air dalam batang yang relatif sama. Berdasarkan Gambar 2, bagian bawah seksi cenderung memiliki kadar air yang lebih tinggi dibandingkan dengan bagian atas, hal 
ini sesuai dengan Siarudin dan Marsoem (2007) bahwa bagian pangkal pohon biasanya memiliki kadar air yang tinggi dan akan menurun secara teratur ke arah ujung pohon. Pada berbagai umur tanaman jati terdapat kecenderungan bahwa semakin tua tanaman jati, semakin rendah kadar air yang dikandung dalam kulit batang tanaman.

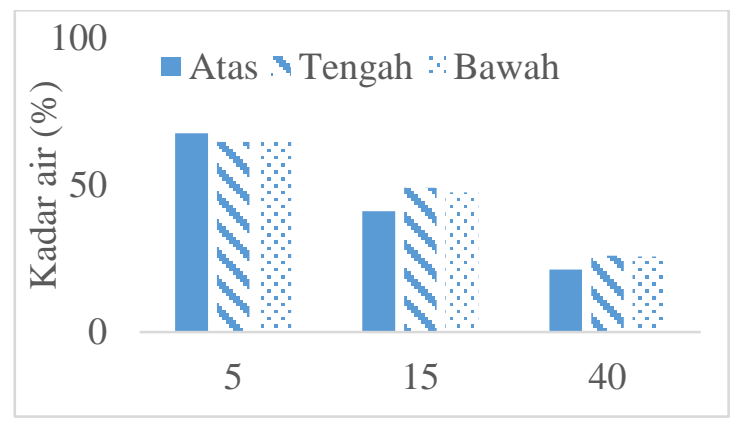

Gambar 2. Rerata Kadar Air Kulit Batang Tanaman Jati Berdasarkan Umur dan Seksi Tanaman

Pada tanaman tua, sel dalam jaringan tanaman mengalami penebalan dan merubah sel parenkim menjadi sklerenkim yang menua. Sklereida dewasa pada jaringan yang menua terdiri dari sel mati, yang memiliki kandungan air yang relatif lebih sedikit dari jaringan muda yang meristematis (Mulyani., 2006). Hal ini dibuktikan juga dengan pernyataan Sutanto (2005), bahwa kandungan air pada tanaman muda lebih tinggi daripada tanaman tua.

\section{b. Tebal kulit batang tanaman}

Kulit tanaman memiliki fungsi untuk melindungi bagian dalam dari tanaman dari pengaruh lingkungan luar, menyimpang cadangan air, dan sebagai jaringan pengangkutan. Hasil analisis varians tebal kulit batang tanaman jati, menunjukkan bahwa umur tanaman jati memberikan pengaruh yang nyata terhadap pertumbuhan kulit batang tanaman jati. Pada berbagai umur, seksi tanaman dari titik yang terdekat dengan permukaan tanah tidak memiliki pengaruh yang nyata pada ketebalan kulit batang tanaman jati. Tebal kulit batang tanaman jati memiliki ketebalan yang relatif sama pada dari seksi terbawah hingga atas.

Tabel 2. Hasil Analisis Varians Tebal Kulit Batang Tanaman Jati Pada Berbagai Umur dan Seksi Tanaman

\begin{tabular}{lrrr}
\hline Sumber variasi & $\begin{array}{c}\text { Derajat } \\
\text { bebas }\end{array}$ & $\begin{array}{l}\text { Jumlah } \\
\text { kuadrat }\end{array}$ & Pr>F \\
\hline Umur & 2 & 109,801 & $\mathbf{0 , 0 0 0 *}$ \\
Seksi & 2 & 1,875 & 0,255 \\
Umur x Seksi & 4 & 0,815 & 0,876 \\
Error & 81 & 54,659 & \\
\hline Total & 89 & 167,149 & \\
\hline
\end{tabular}

Berdasarkan Gambar 3, batang tanaman jati pada umur tua (40 tahun) memiliki pengaruh yang paling signifikan terhadap tebal kulit batang dibandingkan 
dengan umur muda dan sedang. Semakin tua tanaman jati, maka semakin tebal kulit tanaman yang dihasilkan. Kulit pohon yang semakin tebal memiliki kemampuan yang lebih besar untuk bertahan hidup setelah kebakaran terjadi, karena kulit pohon tersebut mampu melindungi bagian kambium tanaman sehingga tidak terjadi kerusakan kambium (Rianawati., 2007).

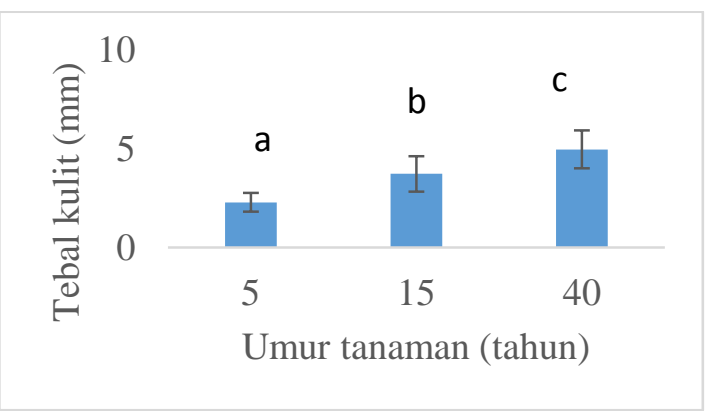

Gambar 3. Rerata Tebal Kulit Batang Tanaman Berdasarkan Umur Tanaman Jati

Ketebalan kulit batang tanaman jati tua (40 tahun) mencapai $5.00 \mathrm{~mm}$ pada setiap seksi tanaman. Kulit batang tanaman jati tua memiliki ketebalan hingga 2 kali lipat dari ketebalan kulit batang tanaman jati muda yaitu $2.3 \mathrm{~mm}$. Hal ini sesuai dengan pernyataan Poli'i (2000) bahwa ketebalan kulit bervariasi menurut jenis, sedangkan pada jenis yang sama akan bervariasi menutu kelas umurnya. Ketebalan kulit kayu juga dapat bervariasi secara vertikal (Paine et al., 2010).

Tebal kulit batang tanaman jati secara vertikal baik pada bagian atas $(100 \mathrm{~cm}$ dari permukaan tanah), tengah $(75 \mathrm{~cm}$ dari permukaan tanah), dan bawah $(50 \mathrm{~cm}$ dari permukaan tanah) tidak memiliki perbedaan yang signifikan, namun relatif sama (Gambar 4).

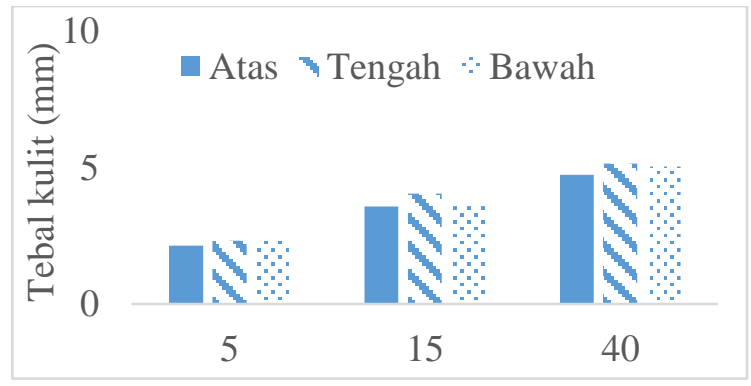

Gambar 4. Rerata Tebal Kulit Batang Tanaman Jati Berdasarkan Umur dan Seksi Tanaman

Pada setiap kelas umur, ketebalan kulit batang tanaman jati memiliki kecenderungan bahwa kulit batang tanaman pada bagian yang dekat dengan permukaan tanah lebih tebal dibandingkan dengan kulit batang yang berada di seksi tanaman bagian atas. 
Pengaruh tebal dan kadar air kulit batang jati terhadap kerentanan kebakaran

Kulit batang merupakan bagian tanaman yang memiliki fungsi untuk melindungi jaringan tanaman yang berada pada bagian dalam. Kulit batang tanaman yang memiliki karakter yang bervariasi dipengaruhi oleh jenis tanaman, umur, dan lingkungan. Pada satu spesies tanaman yang sama, ketebalan kulit batang dan kadar air dapat bervariasi, salah satunya dipengaruhi oleh umur tanaman. Tanaman yang rentan terhadap kebakaran hutan adalah tanaman yang memiliki kulit batang yang cenderung tipis, mudah terbakar, dengan kandungan air yang rendah.

Tabel 3. Hasil Analisis Varians Respon Terbakarnya (Waktu, Detik) Kulit Batang Jati Pada Berbagai Umur Tanaman

\begin{tabular}{lrrrr}
\hline \multicolumn{1}{c}{ Variasi } & $\begin{array}{c}\text { Derajat } \\
\text { bebas }\end{array}$ & $\begin{array}{c}\text { Rerata } \\
\text { kuadrat }\end{array}$ & F hitung & Pr>F \\
\hline Antar variasi umur & 2 & 14261.167 & 69.855 & $\mathbf{. 0 0 0}^{*}$ \\
Dalam variasi umur & 87 & 204.154 & & \\
\hline Total & 89 & & & \\
\hline
\end{tabular}

Hasil analisis varian terhadap respon terbakarnya kulit batang tanaman jati dengan taraf uji 5\% menunjukkan bahwa ketebalan kulit dan kandungan air pada berbagai umur memberkan pengaruh yang nyata. Terdapat variasi atau pengaruh yang signifikan terhadap kerentanan terbakarnya kulit batang tanaman jati. Hasil pengujian lanjut DMRT (Gambar 5) menunjukkan bahwa setiap klasifikasi umur tanaman jati memiliki respon terhadap nyala api yang berbeda. Tanaman jati muda berumur 5 tahun, 15 tahun, dan 40 tahun memiliki respon nyala terhadap api yang berbeda dengan variasi karakter ketebalan kulit kayu dan kandungan air yang berbeda.

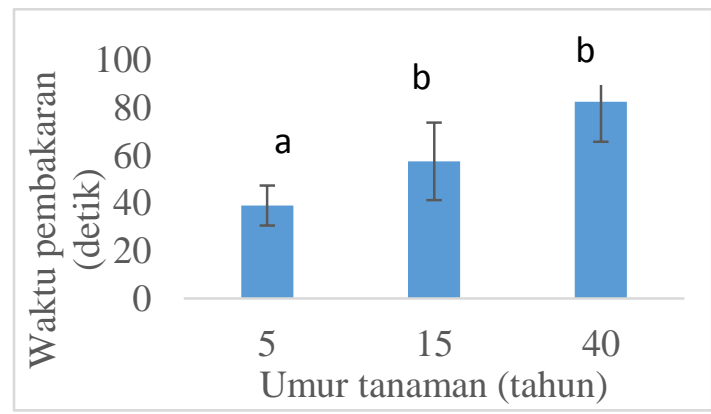

Gambar 5. Rerata Respon Terbakarnya Kulit Batang Berdasarkan Umur Tanaman Jati.

Tebal kulit kayu memiliki hubungan dengan kerentanan suatu tanaman terhadap kebakaran akibat api melalui respon nyala terhadap api (Gambar 6a). Semakin tebal kulit batang tanaman, maka dibutuhkan waktu yang lebih lama untuk membakar karbon pada kulit menjadi abu sisa 
pembakaran. Korelasi tebal kulit kayu terhadap respon terbakar api yaitu sebesar 0.96. Nilai korelasi tersebut cukup tinggi dan erat hubungannya terhadap kerentanan kebakaran. Kulit batang tanaman yang semakin tebal memiliki ketahanan yang lebih baik terhadap api, karena api membutuhkan energi dan waktu yang lebih lama untuk mengubah kulit batang tanaman untuk terbakar secara sempurna. Kulit batang tanaman yang semakin tebal mampu melindungi tanaman pokok yang lebih baik terhadap api, karena dapat menggurangi konduksi suhu api yang tinggi dari api terhadap kambium yang dapat menyebabkan nekrosis kambium (Lawes et al., 2011).

Sifat lain kulit batang tanaman yang mempengaruhi kerentanannya terhadap api yaitu kandungan air dalam kulit batang. Namun, kandungan air pada tanaman jati tidak memberikan pengaruh yang signifikan pada ksifat kerentanan terhadap nyala api. Gambar 6b, menunjukkan bahwa semakin tinggi kadar air yang dimiliki oleh batang tanaman jati, maka waktu yang dibutuhkan untuk terbakar semakin cepat. Hal ini tidak dapat menjelaskan hubungan antara kandungan air dalam kulit kayu terhadap kerentanan terpicu api. Berdasarkan koefisien determinasi yang dihasilkan (51\%), hubungan tersebut tidak mampu menjelaskan nilai kerentanannya terhadap terpicunya api. Nilai koefisien determinasi antara kadar air (\%) dan waktu terbakarnya api mengindikasikan bahwa masih terdapat faktor lain yang memiliki pengaruh lebih tinggi dibandingkan dengan kandungan air dalam kulit terhadap nyala api.

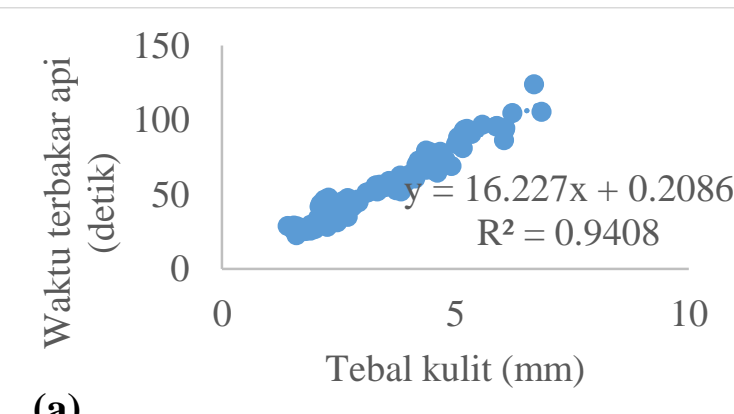

(a)

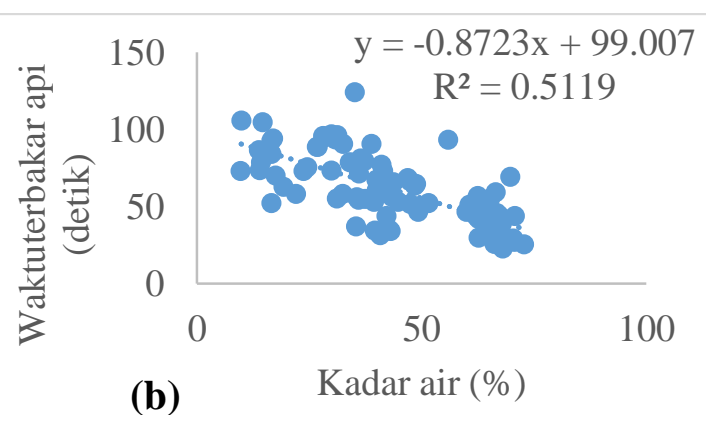

Gambar 6. Hubungan Respon Terbakarnya Kulit Batang Berdasarkan (a) Tebal Kulit dan (b) Kadar Air Kulit Batang Tanaman Jati

Hubungan antara tebal kulit batang tanaman dengan kadar air dalam kulit (gambar 7) menjelaskan bahwa pada 
berbagai umur, kadar air tanaman yang tinggi banyak dimiliki oleh tanaman dengan kulit batang yang cenderung tipis. Pada batang dengan kulit yang tipis, tanaman cenderung lebih cepat untuk terbakar habis apabila terpicu api. Tanaman jati dengan ketebalan kulit yang relatif tebal memiliki kandungan air yang relatif lebih rendah, sehingga waktu yang dibutuhkan untuk membakar kulit menjadi lebih lama.

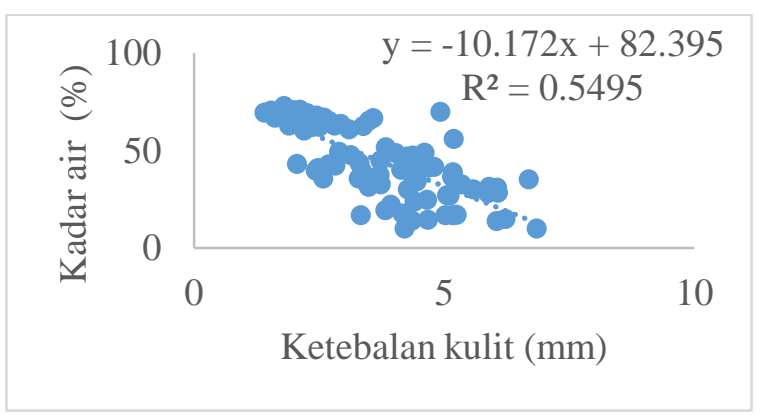

Gambar 7. Rerata Kadar Air Kulit Batang

Tanaman Jati Pada Berbagai

Ketebalan Kulit.

Respon nyala api terhadap kulit tanaman jati pada berbagai umur dengan variasi ketebalan kulit dan kandungan air menunjukkan bahwa tanaman jati dengan umur muda memiliki respon terhadap nyala api yang lebih cepat dibandingkan tanaman dengan umur yang lebih tua. Tanaman jati dengan umur yang muda memiliki kandungan air dalam jaringan kulit yang lebih tinggi namun ketebalan yang dimiliki tidak mampu bertahan dari nyala api yang lebih lama. Tanaman jati dengan umur yang lebih tua memiliki ketahanan yang lebih baik dibandingkan dengan tanaman yang lebih muda dengan waktu pembakaran yang lebih lama. Karakteristik kulit tanaman jati tua yaitu ketebalan lebih tebal namun memiliki kandungan air yang lebih rendah. Hal ini diperkuat dengan hasil penelitian Yulianti et al. (2011) bahwa faktor utama yang menentukan resistensi pohon terhadap api adalah ketebalan kulitnya. Menurut Syaufina (2008), Pohon dengan ketebalan 1,0 hingga $1,3 \mathrm{~cm}$ akan mengakami kerusakan yang ringan jika terbakar. Sehingga, tanaman dengan tebal kulit yang kurang dari $1.0 \mathrm{~cm}$ dapat mengalami kerusakan yang lebih berat. Hal yang membedakan proses pembakaran yang terjadi pada kulit batang tananaman muda dan tanaman tua yaitu pada asap yang dihasilan. Asap yang dihasilkan pada tanaman muda memiliki kuantitas yang lebih banyak dibandingkan dengan tanaman tua, hal ini disebabkan kandungan air pada tanaman muda yang lebih banyak. Mekanisme perlindungan tanaman yang beram seiring dengan umur yang berbeda dapat menyebabkan pohon muda memiliki kulit yang sangat tipis, pohon tua 
mempunya kulit batang yang tebal, dan pohon yang sangat tua mengalami penipisan kulit batang karena tidak produktif lagi (Darwiati dan Tuheteru., 2010).

Dalam kondisi kulit batang yang basah, tanaman jati berumur 40 tahun memiliki berat yang lebih tinggi dibandingan dengan tanaman yang lebih muda (Gambar 8). Kulit batang jati yang lebih tua memiliki waktu pembakaran yang lebih lama dibandingkan dengan tanaman berumur sedang dan muda. Kulit batang jati berumur lebih tua memiliki berat yang lebih tinggi seiring dengan ketebalan kulit yang lebih tebal pula. Berat basah kulit batang tanaman yang berasosiasi dengan ketebalan kulit serta kandungan air tanaman memberikan pengaruh pada waktu pembakaran yang dibutuhkan. Waktu pembakaran kulit batang yang dibutuhkan mengindikasikan tingkat kerentanan kulit batang tanaman terhadap nyala api. Semakin cepat kulit tanaman habis terbakar, maka semakin rentan kulit tanaman tersebut terhadap kebakaran hutan. Hal ini disebabkan kulit kayu, tidak mampu bertahan untuk melindungi bagian dalam jaringan tanaman yang disebabkan oleh api kebakaran hutan dengan intensitas yang beragam sesuai dengan tipe kebakaran dan akumulasi bahan bakar yang ada di sekitar tanaman pokok.

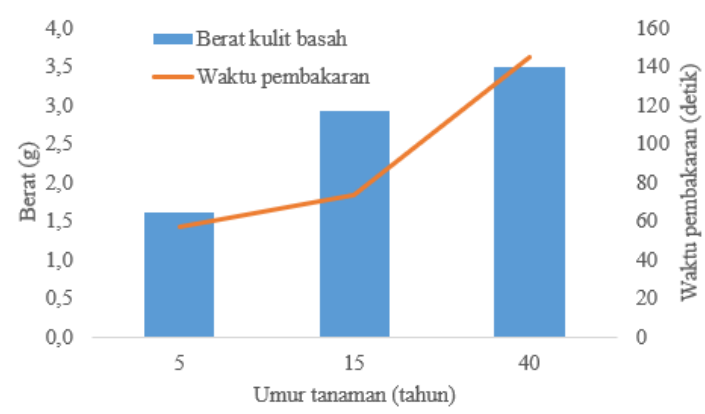

Gambar 8. Rerata Respon Terbakar dan Berat Kulit Batang Berdasarkan Umur Tanaman Jati.

Waktu pembakaran yang dibutukan untuk membakar kulit batang tanaman jati semakin tinggi seiring dengan meningkatnya berat kulit batang tanaman jati. Pada tanaman jati muda, berat kulit yang dimiliki lebih rendah dalam kondisi basah. Namun, pada kulit tanaman jati muda memiliki kandungan air yang lebih tinggi dibandingkan dengan tanaman tua. Meskipun kandungan air yang dimiliki lebih tinggi, tetapi kuantitas bahan bakar yang dapat terbakar pada kulit tanaman muda lebih rendah dibandingkan dengan tanaman tua. Hal ini menyebabkan tanaman jati muda memiliki ketahanan terhadap nyala api yang lebih rendah dibandingkan 
dengan tanaman jati berumur 15 tahun, dan

40 tahun.

\section{Pola Perilaku Api pada Tegakan Jati}

\section{Umur Sedang}

Kebakaran hutan dengan tipe kebakaran permukaan pada pertanaman jati di Petak 17, Wanagama I memiliki beberapa indikator perilaku yang masih dapat terlihat hingga 1 tahun setelah terjadinya peristiwa kebakaran. Pola perilaku api yang tampak digunakan untuk mengidentifikasi kerusakan yang timbul. Pola perilaku api yang masih tampak yaitu bekas kebakaran pada bagian batang tanaman jati. Bekas kebakaran pada bagian batang digunakan untuk menggukut intensitas kerusakan dan model luas kerusakan yang ditimbulkan.

Tabel 4. Pola Perilaku Api Kebakaran Hutan Tanaman Jati Umur Sedang di Petak 17,Wanagama I

\begin{tabular}{lcc}
\hline \multicolumn{1}{c}{ Perilaku api } & Nominal & Satuan \\
\hline Titik bekas kebakaran & $10-350$ & $\mathrm{~cm}$ \\
Persentase bekas & & \\
kebakaran pada batang & $10-100$ & $\%$ \\
Intensitas Kerusakan (IK) & 79 & $\%$ \\
\hline
\end{tabular}

Kebakaran yang terjadi pada petak pertanaman jati di Wanagama I, mampu membakar kulit batang tanaman jati yang bervariasi dari ketinggi $10 \mathrm{~cm}$ hingga 350 $\mathrm{cm}$ dari permukaan tanah. Rendah dan tingginya bekas kebakaran yang ditimbulkan bergantung dari akumulasi seresah maupun tumbuhan bawah sebagai bahan bakar kebakaran. Tanaman jati dengan bekas kebakaran yang tinggi dapat disebabkan oleh akumulasi seresah dan tumbuhan bawah yang tinggi pada bagian lantai hutan dibawahnya dibandingkan dengan area lain. Persentase kulit batang yang terbakar bervariasi dari 10\% hingga 100\%; Persentase kulit batang yang terbakar dapat dipengaruhi oleh distribusi bahan bakar disekitar tanaman pokok, dan arah perambatan api (distribusi api). Arah perambatan api ditentukan oleh arah hembusan angin dan distribusi bahan bakar pada permukaan lantai hutan.

Tabel 5. Klasifikasi Luas Kerusakan Tanaman Jati Akibat Kebakaran Permukaan

\begin{tabular}{ccc}
\hline $\begin{array}{c}\text { Kelas } \\
\text { kerusakan }\end{array}$ & $\begin{array}{c}\text { Tinggi bekas } \\
\text { terbakar }(\mathbf{c m})\end{array}$ & $\begin{array}{c}\text { Luas } \\
(\text { Ha) }\end{array}$ \\
\hline 1 & $<50$ & 0.26 \\
2 & $51-100$ & 1.48 \\
3 & $101-150$ & 1.01 \\
4 & $151-200$ & 0.20 \\
5 & $>200$ & 0.01 \\
\hline \multicolumn{3}{c}{ Total } \\
\hline
\end{tabular}


Kebakaran hutan tanaman jati pada umur 15 tahun menimbulkan kerusakan seluas 2,96 Ha (Tabel 6). Kebakaran tersebut menimbulkan kerusakan tertinggi seluas 0.01 Ha. Kelas kerusakan yang paling luas yaitu kerusakan dengan tinggi bekas terbakar $51-100 \mathrm{~cm}$ dari permukaan tanah. Kerusakan tersebut muncul pada area dengan luasan 1.48 Ha. Hal ini mendukung indikasi bahwa kebakaran permukaan pada hutan tanaman jati menimbulkan bekas kerusakan yang cenderung dekat dengan permukaan tanah. Tipe kebakaran ini terjadi pada area dengan akumulasi bahan bakar yang tinggi berupa seresah maupun tumbuhan bawah pada lantai hutan. Berdasarkan peta klasifikasi kerusakan yang disusun (Gambar 11), kebakaran hutan jati tersebut disebabkan oleh lebih dari 1 sumber api. Hal tersebut diidentfikasi melalui area dengan titik kebakaran yang rendah $(<50 \mathrm{~cm})$ yang berada pada zona kuning. Titik api awal yang terbentuk dan membakar suatu area, umumnya memiliki tinggi bekas terbakar yang rendah kemudian meluas mengikuti pengaruh dari distribusi bahan bakar, topografi, dan angin.

\section{KESIMPULAN DAN SARAN}

Berdasarkan hasil penelitian yang dilakukan, maka dapat disimpulkan bahwa Umur tanaman jati mempengaruhi tebal dan kandungan air dalam kulit batang tanaman jati. Semakin tua umur tanaman jati maka semakin tebal kulit tanaman yang dimiliki, namun kandungan air dalam kulit tanaman semakin rendah. Tebal kulit tanaman jati mempengaruhi kerentanan kebakaran pada berbagai umur. Semakin tebal kulit tanaman, semakin tahan batang untuk terlindung terhadap nyala api. Kandungan air dalam kulit batang tanaman jati juga memberikan pengaruh terhadap ketahanan terhadap nyala api. Kebakaran permukaan yang terjadi pada pertanaman jati umur sedang di Petak 17, Wanagama I, disebabkan oleh sumber api yang lebih dari 1 sumber. Kerusakan terbanyak yang ditimbulkan berada pada ketinggian 50-100 $\mathrm{cm}$ dari permukaan tanah.

\section{UCAPAN TERIMA KASIH}

Terima kasih kepada seluruh pihak yang mendukung penelitian ini, khususnya kepada segenap civitas akademika Fakultas Kehutanan Universitas Gadjah Mada. 


\section{DAFTAR PUSTAKA}

ADPC. 2006. "Hazard, Vulnerability and RiskWorkshop on Earthquake Vulnerability Reduction for Cities and Damage and Loss Estimation for Recovery Planning." Yogyakarta: Research Center for Disaster Studies.

Agency, Japan International Cooperation. 2009. Kajian Tentang Penanggulangan Bencana Alam di Indonesia. Jakarta: Oriental Consultants Asian Disaster Reduction Center.

Akbar, Acep. 2016. Pemahaman dan solusi masalah kebakaran hutan di Indonesia. 1. Bogor: Forda Press.

Baskorowati, Liliana, and Mohamad Anis Fauzi. 2013. "Biologi Jati." In Benih unggul untuk pengembangan hutan jati rakyat, edited by Balai Besar Penelitian Bioteknologi dan Pemuliaan Tanaman Hutan. Bogor: Forda Press.

Forest Watch Indonesia. n.d. Forest Watch Indonesia. Accessed Januari Senin, 2018. fwi.or.id.

Hizbaron, D.R, D.S. Hadmoko, G Samodra, S.A. Dalimunthe, and J Sartohadi. 2010. "Tinjauan Kerentanan, Risiko, dan Zonasi Rawan Bahaya Rockfall di Kulonprogo, Yogyakarta." Forum Geografi 24 (2): 119-136.

Jaswadi, R Rijanta, and Pramono Hadi. 2012. "Tingkat kerentanan dan kapasitas masyarakat dalam menghadapi risiko banjir di kecamatan pasar kliwon Kota Surakarta." Majalah Geografi Indonesia 26 (1): 119-148.

Kementerian Lingkungan Hidup dan Kehutanan. n.d. SiPongi-Sistem Monitoring KarHutLa. Accessed
Januari Selasa,

2018.

sipongi.menlhk.go.id.

Krisdianto, and Ginuk Sumarni. 2006. "Perbandingan persentase volume teras kayu jati tempat tumbuh dan konvensional umur 7 tahun asal Penajam, Kalimantan Timur." Jurnal Penelitian Hasil Hutan 24 (5): 385-394.

Lukmandaru, Ganis, Vendy Eko Prasetyo, Joko Sulistyo, and Sri Nugroho Marsoem. 2010. "Sifat Pertumbuhan Kayu Jati dari Hutan Rakyat Gunung Kidul." Prosiding seminar "Hutan Kerakyatan Mengatasi Perubahan Iklim" 79-86.

Marsoem, Sri Nugroho. 2013. "Studi Mutu Kayu Jati di Hutan Rakyat Gunungkidul I. Pengukuran Laju Pertumbuhan." Jurnal Ilmu kehutanan 7 (2): 108-122.

Marsoem, Sri Nugroho, Eko Vendy Prasetyo, Joko Sulistyo, Sudaryono, and Ganis Lukmandaru. 2014. "Studi Mutu Kayu Jati di Hutan Rakyat Gunungkidul III. Sifat Fisik Kayu." Jurnal Ilmu Kehutanan 8 (2): 75-88.

Pudjiono, Sugeng. 2014. Produksi bibit jati unggul dari klon dan budidayanya. 1. Jakarta: IPB Press.

Rasyid, Fachmi. 2014. "Permasalahan dan Dampak Kebakaran Hutan." Jurnal Lingkar Widyaiswara 1 (4): 47-59.

Rianawati, Fonny. 2007. "Analisa Tebal dan Kadar Air Kulit Pohon Serta Kecepatan Terpicunya Api (Quick-Fire Start) Jenis Gmelina, Sungkai, dan Sengon." Jurnal Hutan Tropis Borneo 8 (21): 71-76.

Sumardi, and S.M Widyastuti. 2007. Dasardasar Perlindungan Hutan. 
Yogyakarta: Gadjah Mada University Press.

Team, National Wildfire Coordinating Group Fire Investigation Working. 2005. Wildfire Origin \& Cause Determination Handbook. Boise: National Interagency Fire Center.

Wahyudi, Imam, Dicky Kristia Dinata Sinaga, Muhran, and Lidia Binti Jasni. 2014. "Pengaruh Jarak Tanam Terhadap Pertumbuhan Pohon dan Beberapa SIfat Fisis-Mekanis Kayu Jati Cepat Tumbuh." Jurnal Ilmu Pertanian Indonesia 19 (3): 204-2010.

Wahyudi, Imam, Trisna Priadi, and Istie Sekartining Rahayu. 2014. "Karakteristik dan SIfat-sifat Dasar Kayu Jati Unggul Umur 4 dan 5 Tahun Asal Jawa Barat." Jurnal Ilmu Pertanian Indonesia 19 (1): 50-56. 